\title{
Valuing The Cost Of Interventions Through Mangrove Rehabilitation: The Case Of Panguil Bay, Philippines
}

\author{
Wilson C. Nabua ${ }^{1}$, Gerrylou Sweet M. Pia ${ }^{2}$, Annielyn Tampus ${ }^{2}$ \\ $\left\{\right.$ wilsonabua@gmail.com $\left.{ }^{1}\right\}$ \\ Northwestern Mindanao State College of Science and Technology, Philippines \\ Mindanao State University-Iligan Institute of Technology, Philippines ${ }^{2}$
}

\begin{abstract}
Mangrove forests are extremely productive ecosystems that provide numerous goods and services both to the marine environment and the people. This study aimed to assess the mangrove forest situation of Panguil $\mathrm{Ba}$ and to value the costs of interventions. Specifically, it sought to determine the mangrove profile of Panguil Bay, assess the population density of the different mangrove species and assesses the performance of the interventions. To determine the population density of mangroves, the actual assessment was conducted through the transect-quadrat method in the mentioned barangays. The results revealed that mangrove forests in Panguil Bay are already in their alarming state. The population declined by more than $50 \%$ for 59 years caused by conversion to fishponds, built-ups, cultivated areas for agriculture and some become part of the sea. The government exerted its effort to rehabilitate the mangrove forests and spent P13,500 per hectare. However, the survival rate of planting was very low with only $29 \%$. Only eight species of mangrove are found in Tangub City under the six families, five of which were included in the Red List of IUCN.
\end{abstract}

Keywords: Mangrove forest, Panguil Bay, valuation, intervention

\section{Introduction}

Mangrove forests provide goods and services to the marine environment and the people. Mangrove ecosystems provide territory and nurseries for many (shell) fish species, crustaceans, and other species. They repossess carbon, eradicate water contaminants and guard coastal cities and agricultural fields against wave impacts, coastal erosions and damaging storms. These form an essential source of food for thousands of coastal communities around the world. However, the mangrove forest is a common resource and the depletion of its resources is already a widespread problem.

Users exploit the resources on the optimum level thinking of their own benefits without considering the welfare of the other users and the future generation. The ultimate end is tragic on the part of the environment where the resources particularly mangrove would become extinct in the future if not addressed immediately.

The Philippine mangrove forests are very much diverse but are facing tremendous threats. Both the natural and anthropogenic factors are very much related to their denudation. The mangrove forests had declined by $30-50 \%$ over the past five decades as a consequence of coastal infrastructure development, aquaculture expansion and over-harvesting [1], [2]. 
Unknowingly, the deforestation of mangrove appears to have adversely affected the poorest members of society more than the wealthier ones [3]. This prompted the government to create programs and projects to save the ecosystem from adversarial phenomena. Despite of the diversity of the Philippine mangrove forests, the reforestation/rehabilitation is a big failure [4]. It is believed that the fisherfolks and other residents near the mangrove ecosystem play a crucial role in conservation. Residents are part of the ecosystem [5]. Thus, there is a need to raise their level of awareness to ensure success of the mangrove rehabilitation project. They reported that when people are not entirely aware, the loss of mangrove forests is greater than rehabilitating the source.

Panguil Bay has a wide mangrove area covering the Cities of Tangub and Ozamiz in Misamis Occidental and several municipalities along the provinces of Zamboanga del Sur and Lanao del Norte. The Cities and municipalities along with the Panguil Bay have considerably a number of hectares mangrove areas of which a portion of these have been declared as protected areas by the Department of Environment and Natural Resources.

Ten years ago, the mangroves were assessed and the researchers found out that a total of 21 true mangrove and 15 mangrove-associated species were identified around the bay and the municipality of Kolambugan had the highest mangrove cover of 139.26 ha with $95 \%$ or 132.31 ha covered [6]. The study also revealed that previous interventions had not improved the mangrove status in the bay due to the continuing massive fish pond development. The DENR has always been active in rehabilitating mangroves applying several strategies for sustainability.

This paper then assessed the present situation of mangrove forests in Panguil Bay and determined the valuation of the costs of interventions. The study aimed to assess the mangrove forest in through valuing the costs of interventions. Specifically, it sought to determine the mangrove profile of Panguil Bay, assess the population density of the different mangrove species, and conduct valuation of the costs of interventions.

\section{Method}

The research was conducted in the mangrove areas of Tangub City as part of Panguil Bay. Secondary data were collected secondary data from the Department of Environment and Natural Resources in Cagayan de Oro City and the City Environment and Natural Resources (CENRO) in the said City. Key Informant Interviews were also conducted to the select Brgy Captains and councilors of Silanga, Maloro, Migcanaway and Mantic. To determine the population density of mangroves, actual assessment through transect-quadrat method in the mentioned barangays were performed.

Published records, actual interviews and site inspection were employed in the study. The assessment of the mangrove ecosystem involved locating the mangrove forest based on published records, actual interviews and inspection of the sites. A number of stations was established per site depending on zonation patterns and extent of the forest cover. Photographs were taken to help in the easy location of the site.

Transect plot technique was used to determine the mangrove community. Plots (10 $\mathrm{m} \times 10$ m) were randomly established in each barangay. Mangroves with (DBH $>4 \mathrm{~cm}$ ) were counted and measured for diameter at breast height. The saplings and seedlings were counted inside the plot [7]. However, in the case where the density of seedlings (height $1 \mathrm{~m}$ ) is high and uniform, a 1 x $1 \mathrm{~m}$ subplot was created for actual counts. Only dominant mangrove species were considered for counting. Diversity, density and basal area were computed using the following definitions and formula[7]; 
Diversity -number of species found per transect

Stem density -number of trees/shrub per plot

$$
\text { Stand density/ha. = }
$$

The primary and secondary data that were collected were analyzed using descriptive statistics.

\section{Result and Discussion}

\subsection{Profile of Mangrove Ecosystem in Panguil Bay}

\begin{tabular}{|c|c|c|c|c|c|c|}
\hline Location & $\begin{array}{l}\text { Mangrove } \\
\text { Cover } \\
\text { (NMRIA } \\
1956)\end{array}$ & $\begin{array}{l}\text { Existing } \\
\text { Mangrove } \\
\text { Stand based } \\
\text { on Google } \\
\text { Imagery } \\
(2015)\end{array}$ & $\begin{array}{l}\text { Mangrove } \\
\text { Area Under } \\
\text { Rehab } \\
\text { projects }\end{array}$ & $\begin{array}{l}\text { Mangrove } \\
\text { Area } \\
\text { Converted } \\
\text { to other } \\
\text { land use }\end{array}$ & $\begin{array}{l}\text { Remaining } \\
\text { Mangrove } \\
\text { Area for } \\
\text { Devt }\end{array}$ & $\begin{array}{l}\text { Total } \\
\text { Actual } \\
\text { Mangrove } \\
\text { Cover }\end{array}$ \\
\hline $\begin{array}{l}\text { Lanao del } \\
\text { Norte*** }\end{array}$ & $5,021.39$ & $2,089.29$ & $1,123.00$ & $2,814.37$ & 6.27 & $3,937.37$ \\
\hline Bacolod & 73.97 & 72.96 & & 47.33 & & 47.33 \\
\hline Baroy & 65.27 & 25.66 & & 55.57 & & 55.57 \\
\hline Kapatagan & 964.77 & 851.48 & 132.00 & 83.36 & & 215.36 \\
\hline Kauswagan & 30.69 & 18.42 & & 22.60 & 1.00 & 22.60 \\
\hline Kolambugan & 180.00 & 87.38 & & 156.78 & & 156.78 \\
\hline Lala & $3,031.98$ & 930.00 & 15.0 & 383.15 & & 398.15 \\
\hline Maigo & 10.38 & 4.30 & & 10.46 & & 10.46 \\
\hline Tubod & 90.00 & 39.66 & 5.00 & 70.47 & & 75.47 \\
\hline Misamis & $3,435.20$ & $1,558.91$ & 496.00 & $2,575.88$ & 22.71 & $3,071.88$ \\
\hline \multicolumn{7}{|l|}{ Occidental $* *$} \\
\hline Bonifacio & & 31.62 & & & & \\
\hline Ozamis City & 360.18 & 29.60 & 4.67 & 300.54 & & 305.21 \\
\hline Tangub City & 495.76 & 80.22 & 16.01 & 269.84 & & 285.85 \\
\hline
\end{tabular}

Table 1. Mangrove Profile in Panguil Bay

Source: Department of Environment and Natural Resources, Cagayan de Oro City

**Total includes all municipalities under the province

Table 1 shows that the mangrove area in the two provinces along the Panguil Bay had decreased by more than $50 \%$ after 59 years. In Lanao del Norte alone, the area had decreased from 5,021.39 to $2,089.29$ or $56.4 \%$ per google imagery. However, the actual mangrove cover is $3,937.37$ hectares in which $2,814.37$ or $71.47 \%$ was converted to other land use such as fishponds, built-ups, cultivated areas for agriculture while some become part of the sea. In Misamis Occidental on the other hand, only $45 \%$ of 3,435.20 remained based on the google imagery. The area converted to other land use reached $84 \%$.

The results imply that the present mangrove forests in Panguil Bay are already in its alarming state. This happened because several decades ago, there was no concrete projection on how would the mangrove degradation affect the environment and even in the existence of 
the people. Several causes of the decrease in the mangrove cover were pointed out by some environmental advocates as anthropogenic or man-made. Increasing populations and coastal developments have caused speedy degradation to mangroves [8], conversion of mangrove to aquaculture/agriculture [1], [9]. As a result, mortality rate of stems in the plantation forests reached $90 \%$ [10], [11].

\subsection{Performance of Mangrove Rehabilitation}

Table 2. Mangrove Rehabilitation in Tangub City

\begin{tabular}{llllcc}
\hline Barangays & $\begin{array}{l}\text { Area Planted } \\
\text { (Hectares) }\end{array}$ & $\begin{array}{l}\text { Number of } \\
\text { Seedlings } \\
\text { Planted }\end{array}$ & $\begin{array}{l}\text { Mortality } \\
\text { Rate } \\
\text { (Percent) }\end{array}$ & $\begin{array}{l}\text { Cost of } \\
\text { Seedling and } \\
\text { Planting (P) }\end{array}$ & $\begin{array}{l}\text { Maintenance } \\
\text { Cost } \\
\text { (Pesos) }\end{array}$ \\
\hline Minsubong & 2.81 & 7,025 & 70 & 29,505 & 16,860 \\
Silanga & 13.03 & 32,575 & 50 & 136,815 & 78,180 \\
Maloro & 1.63 & 4,075 & 55 & 17,116 & 9,780 \\
Migcanaway & 8.56 & 21,400 & 95 & 89,880 & 51,380 \\
Mantic & 4.39 & 10,975 & 95 & 64,786 & 37,020 \\
Garang & 10.65 & 26,625 & 50 & 111,826 & 63,900 \\
Maquilao & 3.07 & 7,675 & 80 & $32,236[8]$ & 18,420 \\
Aquino & 1.53 & 3,825 & 95 & 16,066 & 9,180 \\
Lorenzo Tan & 1.94 & 4,850 & 90 & 20,370 & 11,640 \\
Balatacan & 2.52 & 6,300 & 85 & 26,460 & 15,120 \\
Bocator & 9.43 & 23,575 & 80 & 99,016 & 56,580 \\
Sumirap & 0.76 & 1,900 & 70 & 7,980 & 4,560 \\
Pangabuan & 2.9 & 7,250 & 55 & 30,450 & 17,400 \\
TOTAL/Average & 65.00 & 162,500 & 71.03 & 507,000 & 390,000 \\
\hline Source: City Envin
\end{tabular}

Source: City Environment and Natural Resource Office, Tangub City

Costs of Rehabilitation. Table 2 shows that as of the middle of 2017, the Department of Environment and Natural Resources spent almost a million pesos worth of mangrove tree planting and maintenance of the 65 hectares. The program aims to rehabilitate mangrove forests from their degradation. The responsibility of the implementation of the program was given to the barangays and the DENR does the monitoring. Among the coastal barangays with mangrove rehabilitation program, Silanga has the biggest area planted at 13.03 hectares with more than 32,000 seedlings. Each seedling costs an average of P3.00 excluding maintenance. The government has already spent almost a million pesos to rehabilitate the 65 hectares or P13,800 per hectare.

Expert in mangrove valuation reported that the restoration costs of vegetative cover and ecological functions per hectare ranged from USD\$225/ha to USD\$216,000 [12], while around S\$80000 (2010) and US\$1600000 per hectare for marine coastal habitat. However, planting only as an inexpensive strategy which would costs only between USD\$100 and 200 per hectare had been reported failure due to tidal inundation that disturbed the growth of the seedlings [13]. Survival Rate. Only 3 of 10 mangroves planted had survived. Barangays Migcanaway, Mantic and Aquino had the highest mortality rate of 95\% while Barangays Garang and Silanga had the lowest with 50\%.

The results revealed that the mangrove tree planting activity in Tangub City is failure. Although the tree planting activity was repeated twice or thrice in a couple of years. Informants enumerated some reasons of a very low survival rates such as strong waves during northeast and southwest monsoons, barnacles' (Amphibalanusamphitrite)) infestations, muddy 
substrates, destructive fishing methods and residents' intrusions in the areas for economic activities.

People believe that mangroves plays a very important role as critical barrier to waves and flooding due to their dense root structures and low branches. Thus, these are used in rehabilitating in denuded areas. However, when these are still seedlings, they could not be a barrier to strong waves caused by monsoon winds. The monsoon winds continue to erode mangrove-dominated coastlines [14]. On the other hand, there is still a positive impact if the planters used an effective way in planting such as the change in vegetation that would enhance soil fertility [15].

Another cause of the poor seedling performance had been attributed to the presence of barnacles attached to stems and leaves of mangroves particularly to the Rhizophoraceae family. Informants stressed that it is very difficult to sustain the management of seedlings where barnacles attached because it becomes more laborious. The failure may not only due to the infestation of pests. In fact, reports showed that barnacles are the main causal organism of mangrove seedling damage or death [16], [17]. Two leading factors of poor survival were identified such as: inappropriate species and site selection [18]. Tangub City areas are muddy and only select species of mangrove can survive in the area. In addition, the economic activities of the residents have disturbed the growth of mangroves. Whatever reason is, there is a failure if the government impose a plant only strategy [19]. There should be Ecological Mangrove Restoration (EMR) in which the autecology and community ecology, and normal hydrology of mangroves should be understood first, modifications to hydrology or added stress should be assessed, selection of restoration site, creation or restoration of normal hydrology and plant mangrove only as needed.

Table 3. Mangrove species found in Tangub City

\begin{tabular}{|c|c|c|c|c|}
\hline Mangrove Family & Scientific Names & Common Name & Red List Categories & $\begin{array}{l}\text { Global } \\
\% \text { Loss }\end{array}$ \\
\hline ACANTHACEAE & Acanthus ebractentus & Diliuatiao & Least Concerned & 22 \\
\hline \multirow[t]{2}{*}{ AVICENNIACEAE } & Avicennia alba & Piyape lake & Least Concerned & 24 \\
\hline & Avicennia marina & Piyapebaye & Least Concerned & 21 \\
\hline \multirow[t]{3}{*}{ RHIZOPHORACEAE } & Rhizophora apiculata & Bakhaw lake & Least Concerned & 20 \\
\hline & Rhizophora mucronata & Bakhawbaye & Least Concerned & 20 \\
\hline & Ceriopstagal & Tungog & Near Threatened & 12 \\
\hline SONNERATIACEAE & Sonneratia alba, & Pagatpat & Not in the Red List & \\
\hline PALMAE & Nypafruticans & Nipa & Not in the Red List & \\
\hline
\end{tabular}

A total of 8 mangrove species were identified under the six families. These are Acanthus ebractentus, Avicennia alba, A. marina, Rhizophora apiculata, R. mucronata, Sonneratia alba, Ceriopsdecandra and Nypafruticans (Table 3). The dominant species are Avicennia alba or PiapeLaki. On the other hand, the Ceriopsdecandra (Tungog) had the smallest population with only less than ten trees that can be found in BrgyMaloro. This specie is already endangered and vanishing because this is not fast growing but is in demand by the coconut sap collector as ingredient in coconut wine making. 
The mangrove species were assessed whether they are in the Red List of IUCN, only One specie $(13 \%)$ only partially met the thresholds for a threatened category and was therefore listed as Near Threatened. Five species $(63 \%)$ were assessed as Least Concern. Some of the "Least Concern" species also are considered to be common, fast-growing, early-successional species and the two (Sonneratia alba, Nypafruticans) were not in the red list.

Table 4. Population density

\begin{tabular}{llllll}
\hline & Average & \multicolumn{4}{c}{ Population Density } \\
Various Mangrove Species & & Silanga & Maloro & Migca & Mantic \\
\hline Tree & & & & & \\
$\quad$ Average Height (m) & 21.54 & 23 & 19.57 & 22 & 20.6 \\
$\quad \begin{array}{l}\text { Average Width (cm) (DBH) } \\
\quad \text { Population Density (Hectare) }\end{array}$ & 16.65 & 15.69 & 14.87 & 18.21 & 17.82 \\
$\quad 150$ & 1100 & 1800 & 1,400 & 1900 \\
$\quad$ & & & & & \\
$\quad$ Avering & 1.50 & 1.71 & 1.65 & 1.20 & 1.45 \\
$\quad$ Population Density (hectare) & 1,775 & 1600 & 4800 & 400 & 300 \\
$\begin{array}{l}\text { Propagules } \\
\quad \text { Average Height (cm) }\end{array}$ & 31.57 & 33.67 & 30.55 & 21.56 & 40.5 \\
$\quad$ Population Density (hectare) & 9,700 & 1800 & 9500 & 24,000 & 3500 \\
\hline
\end{tabular}

Table 4 shows that the four barangays assessed, the average population density was only 1,550 with an average width (DBH) of $16.65 \mathrm{~cm}$. The average number of sapling for one hectare was estimated at 1,775 with BrgyMaloro with an estimated population density of 4,800 per hectare. Interestingly, more propagules were found in the area with almost 10,000 stems per hectare with Migcanaway had the highest number of 24,000.

\section{Conclusion}

The mangroves of Panguil Bay area are already in the alarming stage. Among the causes of decline are conversion of the mangroves to land use such as fishponds, built-ups, cultivated area for agriculture and some become part of the sea. The government exerts its effort to rehabilitate the mangrove area but it fails as manifest a very survival rate of seedlings of $29 \%$. It spends P13,000 or more per hectare in rehabilitation excluding the implicit costs incurred by the barangay officials. The causes of very low survival rates are strong waves during monsoon winds, barnacles' (Amphibalanusamphitrite)) infestations, muddy substrates, destructive fishing methods and residents' intrusions in the areas for economic activities.

There are eight dominant species under the five families of mangroves that are found in Tangub City with Avicennia as the dominant specie. The Department of Environment and Natural Resources with the full participation of the Local Government Unit shall take a serious role in mangrove rehabilitation. There is a need for an expert to monitor the rehabilitation activity to ensure high survival rates of reforestation. 


\section{References}

[1] N. Thomas, R. Lucas, P. Bunting, A. Hardy, A. Rosenqvist, and M. Simard, "Distribution and drivers of global mangrove forest change, 1996-2010," PLoS One, vol. 12 , no. $6,2017$.

[2] D. C. Donato, J. B. Kauffman, D. Murdiyarso, S. Kurnianto, M. Stidham, and M. Kanninen, "Mangroves among the most carbon-rich forests in the tropics," Nat. Geosci., vol. 4, pp. 293-297, 2011.

[3] S. Hamilton and S. Collins, "Livelihood responses to mangrove deforestation in the northern provinces of Ecuador," BOSQUE, vol. 34, no. 2, pp. 143-153, 2013.

[4] K. B. Garcia, P. E. Malabrigo, and D. T. Gevana, Philippines 'Mangrove Ecosystem: Status, Threats and Conservation. London: Springer New York Heidelberg Dordrecht, 2014.

[5] M. A. Rahman and Asmawi, "Local Residents' Awareness towards the Issue of Mangrove Degradation in Kuala Selangor," in Malaysia, Procedia - Social and Behavioral Sciences, 2016, p. 222.

[6] PCCAARD, "Managing the mangrove of Panguil Bay.” Philippines, 2007.

[7] M. R. Naguit et al., "Baseline Study for Jose Dalman, Leon Postigo, Liloy, Salug and Sindangan Zamboanga del Norte: Final Report," Regional Fisheries Live."

[8] A. C. H. H. N.Carter, S. W. Schmidt, "International Assessment of Mangrove Management: Incorporation in Integrated Coastal Zone Diversity," vol. 7, pp. 74-104, 2015.

[9] "B.Polidoro, K E. Carpenter1, L Collins, N C. Duke, A. M. Ellison, J C. Ellison, E J. Farnsworth, E S. Fernando, K Kathiresan, N. Koedam, S. R. Livingstone, T Miyagi, G. E. Moore, V. N. Nam, JE Ong, J. H. Primavera, S. G. Salmo, III, J. Sanciangco, S.”

[10] B. B. Walters, "Patterns of Local Wood use and Cutting of Philippine Mangrove Forests," Econ. Bot., vol. 59, no. 1, pp. 66-76, 2005.

[11] G. G. H. H.Nguyen, C. McAlpine, D. Pullar, S J Leiz, "Drivers of Coastal Shoreline Change: Case Study of Hon Dat Coast, KienGiang, Vietnam SpringerScience+Business Media," New York, Environ. Manag., vol. 55, pp. 1093 1108, 2015.

[12] R. R. Lewis, "In review," in Proceedings of the Mangrove Valuation, WorkshopUniversitiSains Malaysia, Penang, 4-8 April, 2001.

[13] E. Bayraktarov et al., "The cost and feasibility of marine coastal restoration," vol. 26, pp. 1055-1074, 2016.

[14] P. G. Roxas and J. G. Gorospe, "Coastal habitat restoration and hydrodynamics in Panguil Bay," in AIP Conference Proceedings, 2007, vol. 898, no. 1, pp. 211-216.

[15] K. A. Kaplan, I. Montero-Serra, E. L. Vaca-Pita, P. J. Sullivan, E. Suárez, and V. L., "Applying complementary species vulnerability assessments to improve conservation strategies in the Galapagos Marine Reserve," Biodivers. Conserv., vol. 23, no. 6, p. 1.

[16] T. Y. Siang, "Effects And Control Of Barnacle Infestation On Mangrove Seedlings In A Mangrove Rehabilitation Site," in Dissertation Submitted In Fulfilment Of The Requirements For The Degree Of Master Of Science, 2013.

[17] J. Y. Wong, H. N. Chen, B. K. Chan, I. Kit Ping Tan, and V. C. Chong, "A combined morphological and molecular approach in identifying barnacle cyprids from the Matang Mangrove Forest Reserve in Malaysia: essentials for larval ecology studies," Raffles Bullet.

[18] J. H. Primavera and E. J. M. A., "A review of mangrove rehabilitation in the 
Philippines: successes, failures and future prospects," Wetl. Ecol. Manag., vol. 16, no. 5, pp. 345-358, 2008.

[19] R. R.Lewis, "Ecological Mangrove Restoration (EMR): Hydrologic Restoration is Critical, Planting Mangroves is Not .PWS President Coastal Resources Group, Inc. (501(c)(3) notfor-profit - tax deductible organization)." Salt Springs, USA, Florida, 2014. 